\title{
Pleomorfik Adenomu Taklit Eden Palatal Minör Tükürük Bezlerinden Kaynaklanan Düşük Dereceli Mukoepidermoid Karsinom: Bir Vaka Raporu*
}

\author{
Low-Grade Mucoepidermoid Carcinoma of Palatal Minor Salivary Glands Mimicking \\ Pleomorphic Adenoma: A Case Report
}

\author{
Duygu AZMAN 1 (D) \\ duygudenti@hotmail.com
}

\author{
Halim GÜLTEKİN² (D) \\ dthalimgultekin@gmail.com
}

\author{
Melek TAȘSÖKER**1 (D) \\ dishekmelek@gmail.com
}

\author{
Alparslan ESEN ${ }^{2}$ iD \\ alparslanesen@gmail.com
}

\section{ÖZ}

Mukoepidermoid karsinom en yaygın görülen malign tükürük bezi tümörüdür. Çoğunluğu parotiste görülür, ancak minör tükürük bezlerinde, özellikle de palatal bölgede sık izlenir. Asemptomatik genişleme şeklinde başlar, fasiyal paralizi ve ağrı oluşturabilir. Histolojik olarak mukoid hücreler, epidermoid hücreler ve şeffaf hücreler içerir. Bu olgu raporunun amacı kliniğimize dental muayene için başvuran 23 yaşında Tip I diyabeti olan kadın hastanın maksilla sağ palatal posterior bölgede yerleşmiş, yüzeyi ülsere olmayan, pembe sağlıklı mukoza ile örtülü şişlik şeklinde izlenen düşük dereceli mukoepidermoid karsinomun klinik ve radyolojik özelliklerini tanımlamaktır.

Anahtar Kelimeler: Karsinom, Mukoepidermoid, Tükürük bezi neoplazmı, Sert damak

$\begin{array}{lll}\text { Geliş: 26.01.2021 Kabul: 16.03.2021 } & \text { Yayın: 30.04.2021 }\end{array}$

\begin{abstract}
Mucoepidermoid carcinoma is the most common malignant salivary gland tumor. Most of them are seen in the parotid gland, but are frequently seen in the minor salivary glands, especially in the palatal region. It begins as an asymptomatic enlargement and may cause facial paralysis and pain. Histologically: contains mucoid cells, epidermoid cells and transparent cells. The aim of this case report is to describe the clinical and radiological features of a 23-year-old female patient with Type I diabetes who admitted to our clinic for dental examination, with low-grade mucoepidermoid carcinoma located in the right palatal posterior region of the maxilla, with a non-ulcerated surface covered with pink healthy mucosa.
\end{abstract}

Keywords: Carcinoma, Mucoepidermoid, Salivary gland neoplasm, Hard palate

$\begin{array}{lll}\text { Received: 26.01.2021 Accepted: } 16.03 .2021 & \text { Published: } 30.04 .2021\end{array}$

Atıf / Citation: Azman D, Gültekin H, Taşsöker M, Esen A. Pleomorfik adenomu taklit eden palatal minör tükürük bezlerinden kaynaklanan düşük dereceli mukoepidermoid karsinom: Bir vaka raporu. NEU Dent J. 2021;1:40-4.

* Bu çalıșma Uluslararası Ağız Kanserleri Kongresi'nde (Eskișehir, 2020) poster bildiri olarak sunumuștur.

** Sorumlu Yazar / Corresponding Author

1. Necmettin Erbakan Üniversitesi, Diş Hekimliği Fakültesi, Ağız, Diş ve Çene Radyolojisi, Konya Türkiye

2. Necmettin Erbakan Üniversitesi, Diș Hekimliği Fakültesi, Ağız, Diș ve Çene Cerrahisi, Konya,

Türkiye

"This article is licensed under a Creative Commons Attribution-NonCommercial 4.0 International License(CC BY-NC 4.0) 


\section{GİRIŞ}

Mukoepidermoid karsinom en yaygın görülen malign tükürük bezi tümörüdür (\%35). ${ }^{1}$ İlk kez 1942 yılında bildirilmiş ve 1945 yılında ayrı bir patolojik antite olarak tanımlanmıstır.2 Tükürük bezi tümörlerinin $\% 15$ 'ini, malign tükürük bezi tümörlerinin \%40'ını oluşturur. Çoğunluğu parotiste görülür, ancak minör tükürük bezlerinde, özellikle de palatal bölgede sık izlenir. ${ }^{3}$ En yüksek sıklık kırklı yaşlarda olmak üzere geniş bir yaş aralığında görülebilmektedir. ${ }^{1}$ Çocukluk çağında da en çok görülen malign tükürük bezi tümörüdür. ${ }^{3}$ Kadınlarda görülme sıklığı biraz daha fazladır. ${ }^{1}$ Baş ve boyun bölgesine radyoterapi uygulanmış bireylerde sekonder tümör olarak da sık ortaya çlkar. Asemptomatik genișleme șeklinde başlar, fasiyal paralizi ve ağrı oluşturabilir. Disfaji ve trismus görülebilir.

Histolojik olarak: mukoid hücreler, epidermoid hücreler ve şeffaf hücreler içerir. ${ }^{3}$ Komşu osseöz yapılarda genellikle yıkıcı değişiklikler oluşturmayan düşük dereceli mukoepidermoid karsinomlar tipik olarak projeksiyon ya da düz grafilerde gözlenememektedir. Bununla birlikte, düşük dereceli mukoepidermoid karsinomlar, kontrastı arttırılmış multidedektör bilgisayarlı tomografi (MDBT) görüntülemede ya da manyetik rezonans görüntüleme (MRG)'de lobüllü ya da düzensiz keskin sınırlı bir görüntü verebilir. Bölgede kistik alanlar bulunabilir ve kalsifikasyonlar ender olarak görülebilir. ${ }^{1}$

$\mathrm{Bu}$ olgu raporunun amacı palatal bölgede teșhis edilen ve pleomorfik adenomaya benzeyen bir mukoepidermoid karsinomun klinik ve radyolojik özelliklerini tanımlamaktır.

\section{OLGU SUNUMU}

Kliniğimize ağız muayenesi için müracaat eden 23 yaşında Tip I diyabeti olan kadın hastanın intraoral muayenesinde, maksilla sağ palatal posterior bölgede yerleşmiş yüzeyi ülsere olmayan pembe sağlıklı mukoza ile örtülü şişlik tespit edilmiştir (Resim 1). Hastanın farkında olmadığı damaktaki șişliğin palpasyonda ağrısız olduğu görülmüştür. Şişliğe komşu dişlerde ağrı ya da perküsyon duyarlılığı benzeri klinik bulgu görülmemiştir.

Bölgenin radyografik incelemesinde panoramik radyografta dişlerde aproksimal çürükler ve periodontitise bağlı horizontal alveolar kemik kaybı dışında patolojik bulgu izlenmemiştir (Resim 2).

Resim 1: İntraoral muayenede tespit edilen sağ maksillar posterior bölgede yerleşmiş yüzeyi ülsere olmayan pembe sağlıklı mukoza ile örtülü șişlik

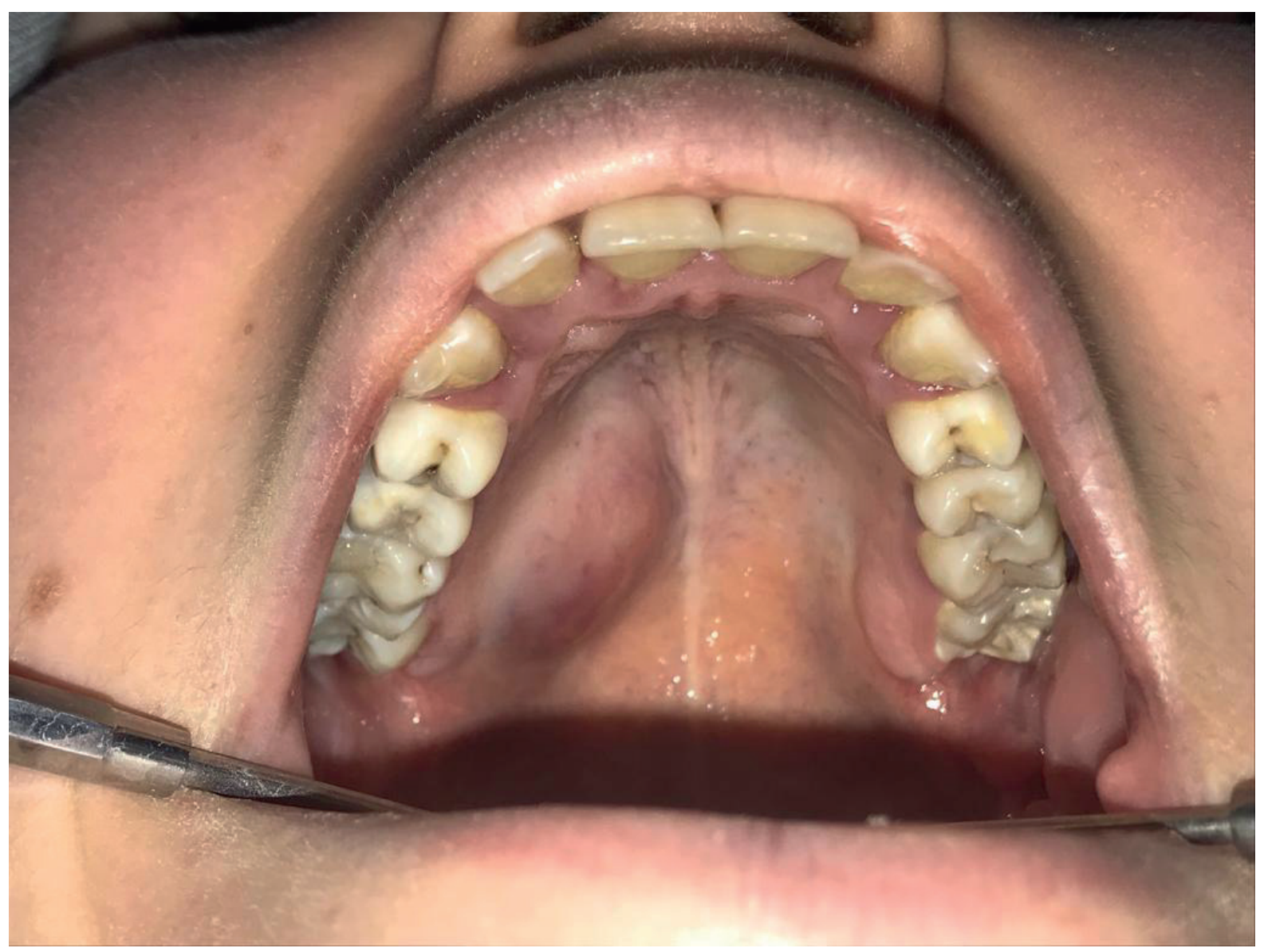


Resim 2: Hastanın panoramik radyografisinde dişlerde aproksimal çürükler ve periodontitise bağlı horizontal alveolar kemik kaybı dıșında patolojik bulgu izlenmemiștir.

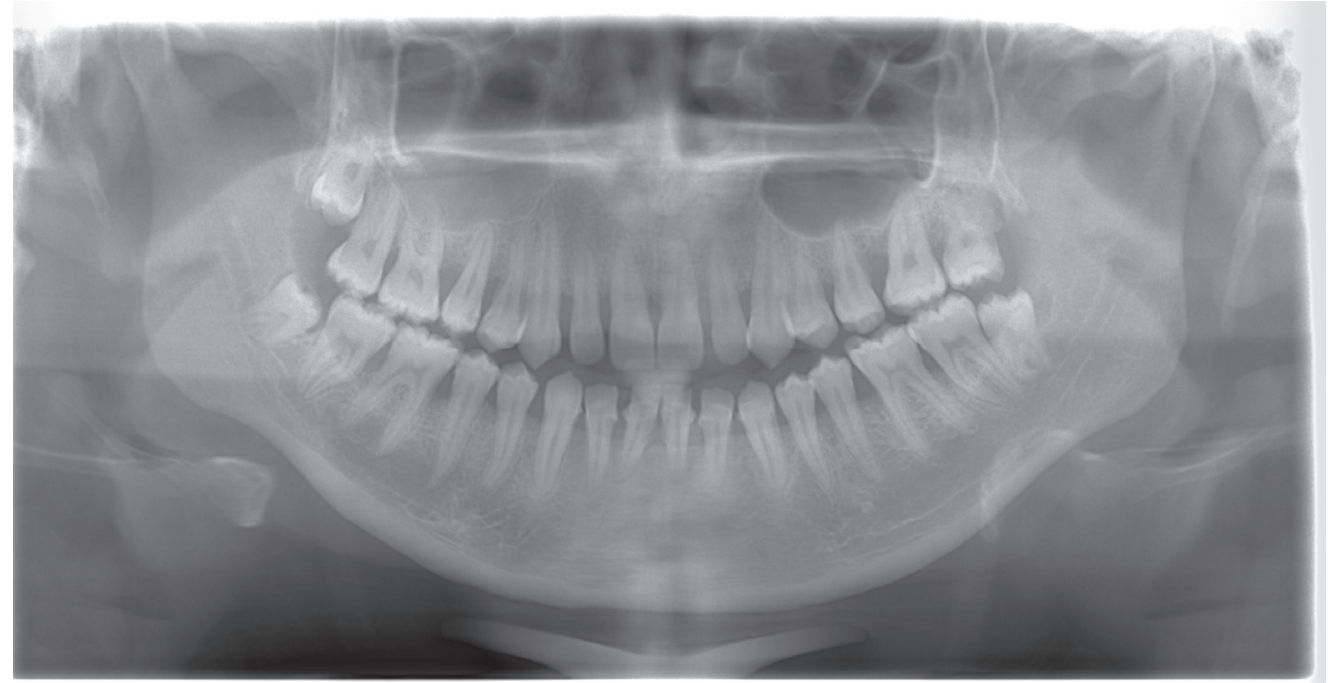

Hastadan yapılan konik ıșınlı bilgisayarlı tomografi (KIBT) incelemesinde bölgedeki şişliğin palatal kemikte destrüksiyona yol açmadığı tespit edilmiştir. Koronal, aksiyal ve sagittal kesitlerde lezyonun yerleştiği yumuşak doku bölgesinde ekspansiyon tespit edilmiştir (Resim 3-5). Şişliğin yumuşak doku odaklı olduğu düşünülerek hasta tükürük bezi tümörü ön tanısıyla Ağız, Diş ve Çene Cerrahisi Anabilim Dalı'na yönlendirilmiştir. Hastaya Ağız, Diş ve Çene Cerrahisi Kliniği'nde ön tanı için ilk olarak iğne aspirasyon biyopsisi uygulanmıș ve aspirasyonda herhangi bir sıvı çekilememiştir. Bu bölgede kitlenin uzun süre bulunduğu ve yavaş büyüdüğü de göz önünde tutulmuş ve kitlenin ön tanısı olarak pleomorfik adenoma düşünülmüştür. Ancak insizyonel biyopsi sonucunda lezyonun histopatolojik olarak düşük dereceli mukoepidermoid karsinom ile uyumlu olduğu saptanmıştır. Daha sonra hasta genel anestezi altında çene cerrahları tarafından opere edilmiştir. İşlem sırasında kitle mukozada sağlıklı dokuları içine alacak şekilde kemik dokuya kadar tamamen çıarılmıştır. Kitle altında kalan kemikten de örnekler alınmıștır. İşlem sirasında major palatin arterde kanama meydana gelmiş ancak arter kanaması koterlenerek tamamen durdurulmuştur. İkinci biyopsi sonucunda kitlenin sağlıklı sınırları içerdiği ve tamamen eksize edildiği bildirilmiştir. Ayrıca biyopsi raporunda kemikte herhangi bir invazyona rastlanmadığı da belirtilmiștir.
Resim 3: Aksiyal KIBT kesitinde lezyonun yerleştiği yumuşak doku bölgesindeki ekspansiyon oklarla gösterilmiştir. Sert dokuda yıkım görülmemiştir

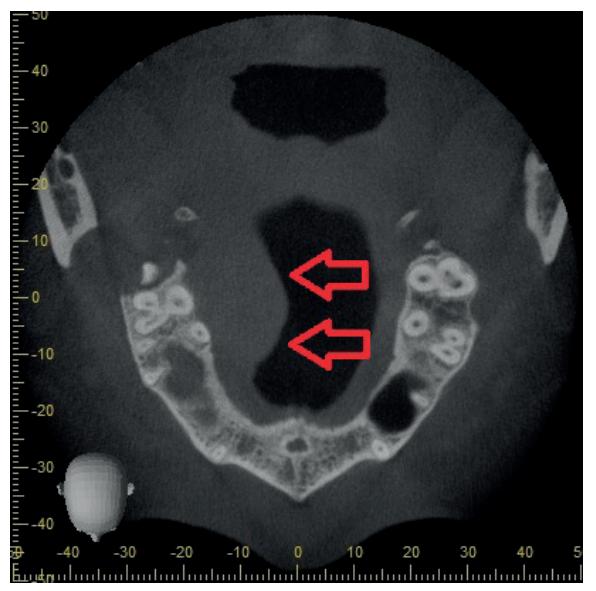

Resim 4: Koronal KIBT kesitinde lezyonun yerleştiği yumuşak doku bölgesindeki ekspansiyon okla gösterilmiştir. Kemikte destrüksiyon izlenmemiștir

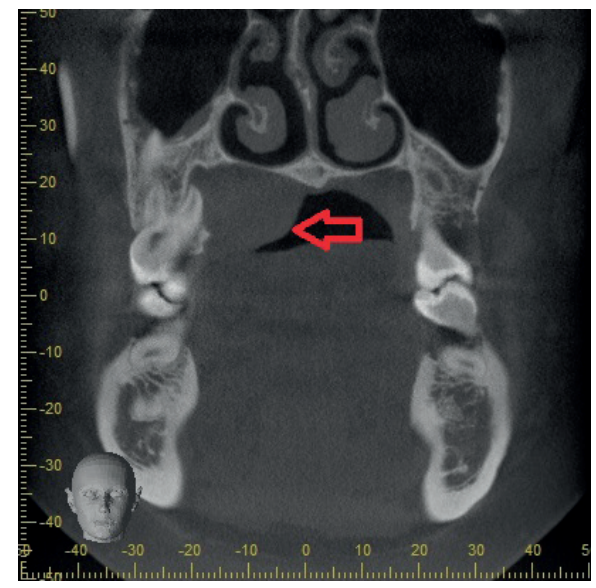

Resim 5: Sagittal KIBT kesitinde lezyonun yerleştiği yumuşak doku bölgesindeki ekspansiyon oklarla işaretlenmiștir. Sert dokuda destrüksiyon bulunmamaktadır

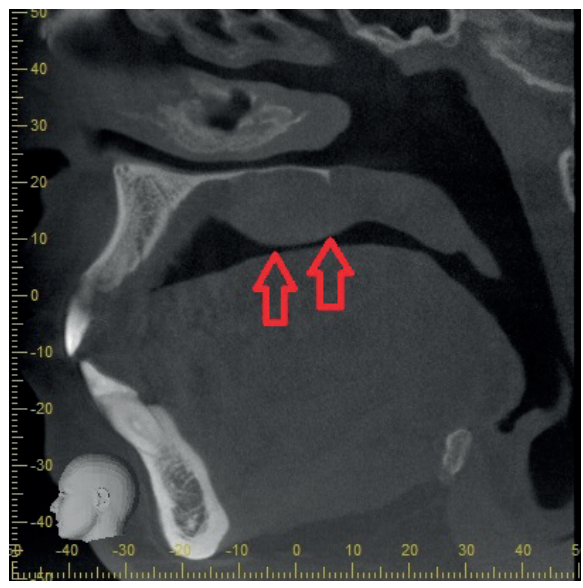


Bölge sekonder iyileşmeye bırakılarak hastanın haftalık kontrolleri yapılmıștır. Postoperatif dönemde radyoterapi uygulamasına onkologlar tarafından gerek görülmemiștir. İki yıldır takip altında bulunan hastamızda rekürrens görülmemiș ve mukozasında tamamen iyileşme sağlanmıștır. Bununla birlikte bu bölgede kemik örnekleri alınan bölgelerde iki alanda oronazal fistül oluşmuştur (Resim 6). Bu yüzden takip döneminde hastanın hayat kalitesini artırmak amacıyla yemek yerken kullanabileceği bir palatal plak da uygulanmıştır. Bu fistülün kapatılması için cerrahi planlama yapılmıştır.

Resim 6: Kemik örnekleri alınan bölgelerde iki alanda gözlenen oronazal fistül

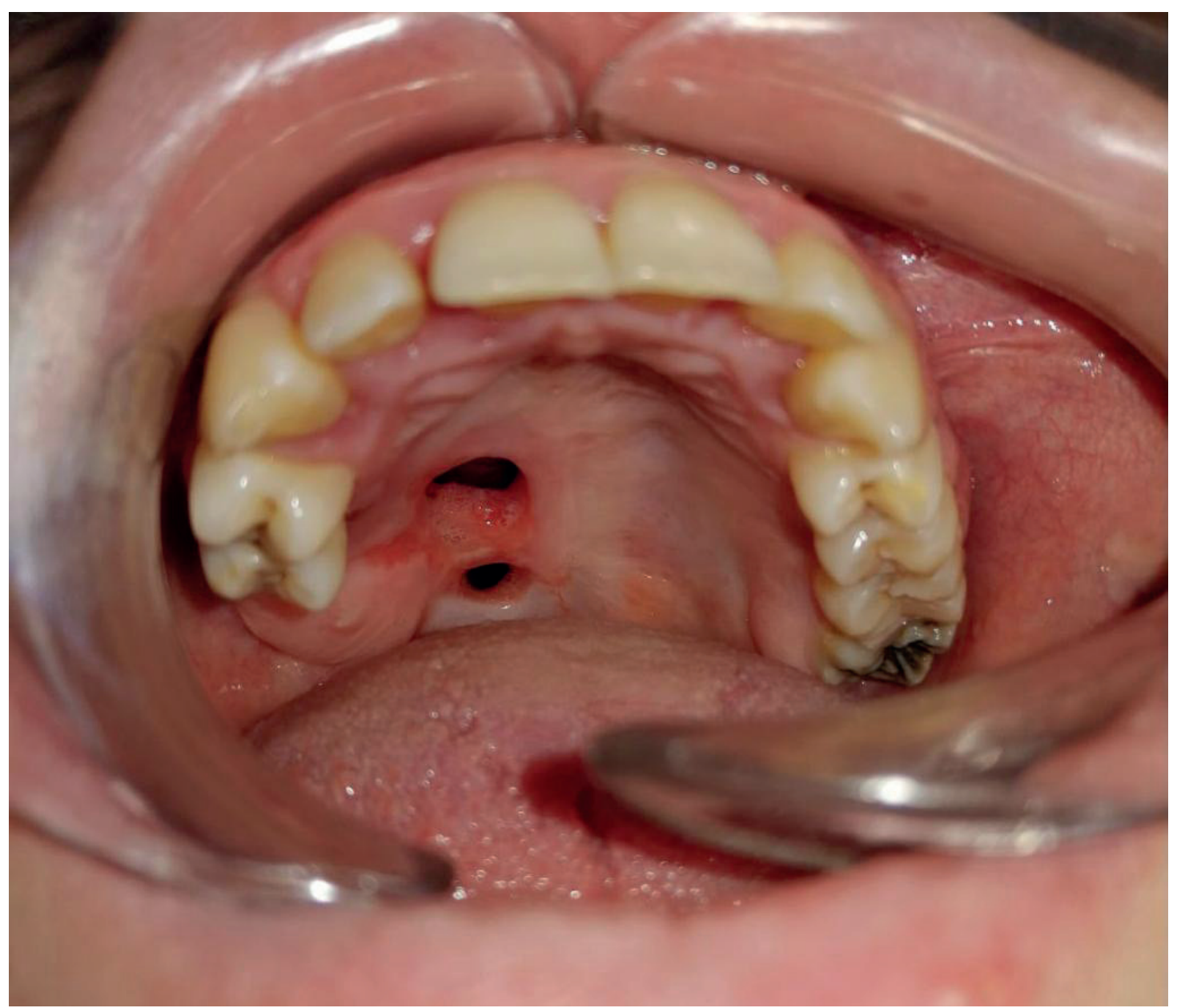

\section{TARTIŞMA}

Minör tükürük bezi tümörleri nispeten nadir görülür ve bu tümörlerin \%44'ünün malign olduğu bildirilmiştir. ${ }^{4,5}$ Mukoepidermoid karsinom oral kavitenin epitelyal tükürük bezi neoplazmıdır ve olguların üçte ikisi parotiste, üçte biri minör tükürük bezlerinde bildirilmiștir. Minör tükürük bezlerinde görüldügünde damak, retromolar bölge, ağız tabanı, bukkal mukoza, dudaklar ve dilde yerleșim gösterir. Nadiren primer çene tümörü olarak ya da laringeal, lakrimal, nazal, paranazal, trakeal ya da pulmoner tümör olarak da karşılaşılabilir. ${ }^{6}$ Histolojik olarak düşük, orta ve yüksek dereceli olarak sinıflandırırlar. Yüksek dereceli tümörlerde artan atipi ile birlikte baskın yapı solid ${ }^{6}$ iken düşük dereceli lezyonlar kistik yapıdadır. ${ }^{7}$ İntraoral mukoepidermoid karsinomların çoğu düşük derecelidir ve bu nedenle yeterli eksiz- yon yapıldığında prognozları iyidir. ${ }^{4}$ Submandibular bez dışındaki bölgelerde yerleștiklerinde 5 yıllık sağ kalım oranları \%90-100'dür.8 Düșük ve orta dereceli tümörlerin nüks oranları <\%10'dur. ${ }^{7}$

Mukoepidermoid karsinomanın kadınlarda daha sık olmakla birlikte genellikle 5. dekad dolaylarında görüldügü bildirilmektedir. ${ }^{9} 2012$ yılında Ord ve Salama tarafından yürütülen çalışmada ${ }^{4}$ palatal bölgede mukoepidermoid karsinom tanılı (17'si düşük dereceli, 1 'i orta dereceli) 18 vakanın değerlendirmesinde 11 hastanın kadın, 7 hastanın erkek olduğu ve yaş ortalamasının 44 olduğu ancak yaș aralığının oldukça geniş (13-80) olduğu bildirilmiştir. Bu çalışmada sunulan hasta ise 23 yaşında ve kadın olup literatürde bildirilen vakaların yaş ortalamasının altında görülmektedir. 
Palatal bölgedeki yumuşak doku şişliklerinin çeşitli nedenleri olabilir. Bu şişlikler dental muayene sırasında basit enfeksiyonlar olarak düşünülmekle birlikte asemptomatik neoplazmlar da olabilmektedirler. ${ }^{9}$ Klinik ve radyolojik olarak karakteristik özellikler taşımadıklarından odontojenik kistleri, ${ }^{10}$ en sık görülen tükürük bezi tümörü olduğu için de pleomorfik adenomu düșündürebilirler. ${ }^{9}$ Lezyonlar genellikle yavaş büyüyen, düzgün yüzeyli ve ağrısız şişlikler olarak ortaya çıkar. Yüksek dereceli tümörlerde ağrı ve fasiyal sinir parestezisi görülebilir. ${ }^{9} \mathrm{Bu}$ vakada da hasta lezyonun asemptomatik olması nedeni ile kitle büyük olmasına rağmen ağzındaki lezyonun tam olarak farkında değildi ve diş hekiminin intraoral muayenesi sırasında tespit edildi. Tümöre ilişkin ağrı ve parestezi bulunmamaktaydı. Düşük dereceli mukoepidermoid karsinom semptomsuz ve yavaș büyüme gösterirken, yüksek dereceli olanlarda hızlı gelişme ve beraberinde ekstraoral ülserasyonlar görülebilir. Komșu dokulara infiltre olurlar ve genellikle lenf nodları, akciğer ve kemiğe metastaz yaparlar. ${ }^{9}$ Diș köklerinde rezorbsiyon ve mobilite varlığı tümörün alveolar kemiği infiltre ettiğinin bir göstergesi olabilir. ${ }^{11} \mathrm{Bu}$ vakada yapılan klinik muayenede dişlere ilişkin patolojik mobilite saptanmadı ve yapılan KIBT incelemesinde bölgedeki şişliğin palatal kemikte destrüksiyona yol açmadığı tespit edildi. Osteolitik yapı gösterdiği durumlarda bu malign lezyonun sebep olduğu destrüksiyon ve ekspansiyonun ortaya konulması bakımından bilgisayarlı tomografi altın standart olarak kabul edilmektedir. ${ }^{10}$

Yeterli örnek alınamaması ya da patoloğun subjektif kanaati nedeni ile tümörün histopatolojik tanısında-derecelendirmesinde problemler olabilmektedir. $\mathrm{Bu}$ nedenle cerrahi planlamada preoperatif radyolojik inceleme ve tanı oldukça önemlidir. Kashiwagi ve ark. ${ }^{12}$ mukoepidermoid karsinom tanısı alan 20 hastanın histolojik tanısı ve MRG bulgularını incelemişler ve tümörün histolojik evresi ile radyolojik bulgularının korelasyon gösterdiğini bildirmișlerdir. Düșük dereceli tümörlerin kistik yapısı MRG'de T2 ağırlıklı görüntülerde hiperintens olarak izlenirken, düzensiz marjinler yüksek dereceli tümörleri tanımlamaktadır. Bununla birlikte düșük dereceli mukoepidermoid karsinomaların yarısında peritümoral enflamatuvar reaksiyona bağlı olarak düzensiz marjinler görülebilmektedir. ${ }^{12} \mathrm{Bu}$ nedenle yalnızca radyolojik görüntülemeye dayanarak tümörün tanısını, derecesini belirlemek doğru olmayacaktır.

Her ne kadar düşük dereceli mukoepidermoid karsinomlarda nüks riski az olsa da bu risk göz önünde tutularak bölgeye cerrahi sonrası immediat olarak bir flap operasyonu düşünülmemiş ve işlem sonrası bölgenin sekonder iyileşmeye bırakılması uygun görülmüştür. Bölgenin uzun süre takip edilmesinin en önemli sebeplerinden biri de hastanın Tip I diya- beti olmasıdır. Bölgede yara iyileşmesi geciktiği için oronazal fistülün kapatılması amacıyla planlanan ikinci cerrahi işlemin de uzun süre ertelenmesi gerekmiștir. Bu dönemde hastanın hayat kalitesini artırmak amacıyla yemek yerken kullanabileceği palatinal bölgeyi kapatan bir plak uygulamasının doğru olacağını düşünmekteyiz.

\section{SONUC}

Düşük dereceli mukoepidermoid karsinomların asemptomatik olduğu ve palatinal bölgede oluşanların pleomorfik adenoma ile karışabileceği akılda tutulmalıdır. Erken evrede teşhis ve tedavinin uygulanması ile morbiditenin azaltılması ve hasta prognozunun iyileștirilmesi mümkündür. İleri yaşlarda nüks eğilimi gösterebilen bu tümörün klinik ve radyolojik takibi hayati önem tașımaktadır.

\section{KAYNAKLAR}

1. White S, Pharoah M. Oral Radiology Principles and Interpretation. $7^{\text {th }}$ Ed. St. Louis: Mosby; 2014.542 p.

2. Gill S, Mohan A, Aggarwal S, Varshney A. Mucoepidermoid carcinoma of hard palate. Indian J Pathol Microbiol. 2018; 61: 397-398.

3. Günhan Ö. Oral ve Maksillofasiyal Patoloji. Quintessence. 2015. 193 p.

4. Ord RA, Salama AR. Is it necessary to resect bone for low-grade mucoepidermoid carcinoma of the palate? Brit J Oral Max Surg. 2012; 50: 712-714.

5. Pires FR, Pringle GA, de Almeida OP, Chen SY. Intra-oral minor salivary gland tumors: a clinicopathological study of 546 cases. Oral Oncol. 2007; 43: 463-470.

6. Jarde SJ, Das S, Narayanswamy SA, Chatterjee A, Babu C. Mucoepidermoid carcinoma of the palate: A rare case report. J Indian Soc Periodontol. 2016; 20: 203-206.

7. Mathew AL, Joseph BB, Sarojini DM, Premkumar P, Nair SS. Mucoepidermoid carcinoma of palate - a rare entity. Clin Pract. 2017; 7: 1009-1009.

8. Triantafillidou K, Dimitrakopoulos J, Iordanidis F, Koufogiannis D. Mucoepidermoid carcinoma of minor salivary glands: a clinical study of 16 cases and review of the literature. Oral Dis. 2006; 12: 364-370.

9. Adiloğlu S, Ergezen E, Aktaș A, Avağ C, Uçar D. Mucoepidermoid carcinoma localized in palate: 3 cases and review of the literature. Clin Dent Res. 2017; 41: 132138.

10. Şençimen M, Ortakoğlu K, Kahraman M, Gülses A, Günhan Ö. Odontojenik Kisti Taklit Eden Maksiller Mukoepidermoid Karsinoma: Vaka Raporu. J Clin Anal Med. 2011; 2: 40-42.

11. Ritwik P, Cordell KG, Brannon RB. Minor salivary gland mucoepidermoid carcinoma in children and adolescents: a case series and review of the literature. J Med Case Rep. 2012; 6: 182-182.

12. Kashiwagi N, Dote K, Kawano K, Tomita Y, Murakami T, Nakanishi K, Araki Y, Mori K, Tomiyama N. MRI findings of mucoepidermoid carcinoma of the parotid gland: correlation with pathological features. Brit J Radiol. 2012; 85: 709-713. 